\title{
THE INFLUENCE OF BRAND EXPERIENCE AND SERVICE QUALITY TO CUSTOMER LOYALTY MEDIATED BY CUSTOMER SATISFACTION IN STARBUCKS COFFEE MALANG
}

\author{
Nolita Aldeline Devia, S.Ikom 1 *, Dr. Siti Aisjah SE., MS 2 *, Dr. Astrid Puspaningrum, SE., MM 3 * \\ 1 * Faculty of Economics and Business, University of Brawijaya, Malang, Indonesia \\ 2 * Faculty of Economics and Business, University of Brawijaya, Malang, Indonesia \\ 3 * Faculty of Economics and Business, University of Brawijaya, Malang, Indonesia
}

\begin{abstract}
This study discusses the effect of Brand Experience and service quality on customer loyalty mediated customer satisfaction. The purpose of this study was to determine and analyze in depth the effect of brand experience and service quality on customer loyalty mediated customer satisfaction at Starbucks Coffee Malang. This research uses explanatory research that explain the causal relationship between the variables studied.By using a survey of 180 respondents to test the research hypothesis. Research data analysis using the test instrument, the classical assumption test, multiple linear regression, and path analysis / Path Analysis. The test results prove the instrument has met the criteria of validity and reliability, the classic assumption test results also have met the criterion of the assumptions of normality, autocorrelation, Non-Multicolinearity and heterocedastisity. In this study obtained; a). Brand experience on consumer satisfaction with the value of 0.309 , or $30.9 \%$, b). The quality of service to customer satisfaction with the value of 0.387 or $38.7 \%$., C). Brand experience on consumer loyalty to the value of 0.216 or $21.6 \%$., D). Service quality on customer loyalty with a value of 0,305 or $30.5 \%$., E). Effect of brand experience and service quality customer satisfaction with the value of 0.581 or $58.1 \%$., F). Effect of brand experience and service quality on customer loyalty with a value of 0.657 or $65.7 \%$., G). Effect of brand experience and service quality on customer loyalty mediated consumer satisfaction with the value of 0.438 or $43.8 \%$. Based on these results, it is necessary to enhance the consumer's commitment to give satisfaction to the consumers better by excellent service or "service excellence" is the attitude and serve with satisfactory manner from the present level while maintaining the brand experience Starbucks Coffee Malang.
\end{abstract}

KEYWORDS: Brand experience (Sensory, Affection, Behavior, Intellectual), Quality of service (reliable, responsiviness, empathy), loyalty, customer satisfaction.

\section{INTRODUCTION}

Along with the growing age, people of the city at this time has undergone a change in lifestyle (lifestyle). One of the manifestations of today's modern lifestyle is the habit of certain groups of people hanging out in the cafe or coffee shop. Starbucks Coffee is a coffee shop network of US-based Seatlle, Washington. Starbucks Coffee is the largest coffeehouse company in the world, with 15012 shops in 44 countries. Starbucks sells coffee, espresso-based hot drinks, other hot and cold drinks, snacks, as well as cups and coffee beans. Starbucks coffee was first opened in 1971 in Seatlle by Jerry Baldwin, Zev Siegle, and Gordon Bowker. The first Starbucks outside Seatlle is in Vancouver and Chicago in 1987 while the first branch outside North America is located in Tokyo,

Companies that have a future view to advancing their business needs to consider various aspects in achieving excellence. The changing nature of today's market is from sellers market into a buyers market, resulting in the consumer becoming increasingly powerful in the market, and increasing competition in the business. Hence the business owners and business people should be able to formulate business strategies that can address those impacts, it is necessary for the survival of the business is managed.

brand experience contains the promise of the company to consistently deliver the characteristics, benefits, and certain services to consumers. In addition, if the quality can provide functional benefits to consumers, so the brand can provide additional benefits that are more emotional and psychological related to the consumer, such as prestige, confidence, hope, pride, and others. Therefore put the brand as one of the components of asset competitive advantage, in addition to quality and price is the right strategy. Moreover, if manufacturers can manage all three correctly, it will create a synergy that mutual support among the three, and the synergy in turn can provide advantages for the company in competition, (Kusuma, 2014) 
According to marketing expert customer satisfaction and loyalty is influenced by the assessment of the results, the interaction and the quality of the physical environment. Customer satisfaction also depends on many factors such as product or service features, consumer emotion, attributes the success or failure of services, perceptions of fairness and justice as well as other consumers such as family members or coworkers (Zethaml, 2006). On the other hand, customer satisfaction can also have an impact on loyalty, their satisfactory service to customers to be part of a more penitng to increase loyalty.

Consumer satisfaction is feeling happy or disappointed someone arising from comparing the perceived performance or results against the expectations of consumers of products and services produced. The creation of customer satisfaction can provide a variety of benefits, including the relationship between the company and customers into a harmonious, providing a good basis for the re-purchase and creation of customer loyalty and establish a recommendation by word of mouth (word of mouth) are favorable for the company. Providing customer loyalty as a commitment which is held in sufficient depth to support the re-purchase or preferred products or services, thus causing heavy customers to switch to other products and services (Kotler, 2016).

Relationships brand experience customer loyalty demonstrated by Anthony (2013) to get the result that the overall brand experience does not have a significant relationship with customer loyalty. The study then describes the significant influence of service quality on customer loyalty. Research conducted Iskandar (2013) resulted in no significant effect on the brand experience with loyalty, then the results of his research further states brand experienceand satisfaction jointly effect on loyalty

Then according Delby (2014), dimensional brand experience consists of four dimensions: entertainment, educational, esthetic, and escapist entertainment has proved that a significant relationship to consumer loyalty. Then educational nothing to do with consumer loyalty, for esthetic is also no correlation with consumer loyalty, and escapist have a significant relationship to consumer loyalty. The variable quality of service study proves that there is significant influence of service quality on customer loyalty.

Starbucks Coffee Shop is a company that already has a very strong brand, and consume coffee products is an old phenomenon that exists in human life, according to one coffee consultant in Indonesia, "Now almost all corners of the city can be assured there is a coffee shop. Usually, visitors will linger at the coffee shop for a cup of coffee, pastries, and talk or chat ", (Taroepratjeka, 2013)

Market leader position held by Starbucks Coffee, arguably the sweet fruit of human technology strategies that have been formulated. The purpose of this strategy is that Starbucks Coffee prefer to use the emotional approach in its marketing. For the coffee mania in Malang, Starbucks Coffee has the distinct impression that is considered capable of providing an emotional attachment to the customers. There are quite a lot of factors that underlie the assessment of customer satisfaction and loyalty, so companies need to carefully examine it. Attention to the brand experience and service quality is one of the strategies that can be undertaken by the company to improve the competitive position,

Research Edmond (2015) stated brand experience consisting of sensory, affective, intellectual, and behavioral prove to sensory, affective and behavioral has a significant relationship to consumer loyalty. While intellectual nothing to do with loyalty. For variable quality of service overall research proves there is significant influence of service quality on customer loyalty.

The concept of brand is one fairly important part of the first phase of creation of products and services. In developing a marketing strategy for individual products, sellers must face the decision to give the brand a major problem in the product and services strategy. Develop branded products require spending a great longterm investment, particularly for advertising, promotion, and packaging. A brand is essentially a seller's promise always mamberikan set of special features, benefits, and services to buyers, (Kotler, 2016).

Always bring the best brand quality assurance, could even constitute a complex symbol. The challenge in branding is to float a package of deep meaning for the brand. According to Kotler (2016) deep meaning of a brand can be known if all six dimensions of the brand, such as the attributes, benefits, values, culture, personality, and users can be visualized.

Brand is very important, because the brand management is the process to control everything done and said by the brand, as well as 
a way of perceiving the process. Brand intangible assets and tangible, makes it relatively difficult to be imitated by competitors. If managed properly will provide benefits for the corporation that owned, among others, can be used as a means of differentiating products company with competitors, open access more easily to the market and new industries, providing sales ratio, and bring profit that is sustainable, (Rangkuti, 2008).

According Brakus et al (2009) Brand experience is defined as sensations, feelings, cognition and consumer response generated by the brand, associated stimuli generated by the brand design, brand identity, marketing communications, people and the environment are marketed brands. In order to define more about the brand experience,

According Brakus et al. (2009) there are four dimensions of brand experience is a sensory dimension, creating an experience through sight, sound, touch, smell, and taste. Then affection, feeling approach to influence moods, feelings and emotions. Then behavior, create a physical experience, patterns of behavior, lifestyles of consumers. Intellectual is the dimension of the latter is to create an experience that encourages consumers involved in thinking carefully about the existence of a brand.

brand experienceor experience the brand is conceptually different from that of other brands, because the brand experience is a concept that describes the customer relationship with the brand that is formed on the responses subjectively, internal (feelings, sensations, and knowledge) and customer behavior is influenced by stimuli associated with and part from design and brand identity, packaging, communication and environment (Brakus, 2009).

Services (services) are activities, benefits or satisfaction offered for sale, or service is an activity that can be identified separately are essentially no palpable (intangibles), which is the fulfillment of the needs and should not be tied to the sale of products or services of others, to produce services may need or may not be necessary to use real objects (tangibles). However, even though the use of objects that need, but there is not any transfer of property rights on the object, (Lamb, 2008).

Quite a lot of different opinions about the definition of quality, because quality has a relative measure of a good or service is considered of attributes, design and suitability for buyers. According to Deming in Supranto et.al (2011) quality is defined as appropriate, in accordance with requirements, free of irregularities, and so on. According to Lamb (2006) gives a sense of quality as the overall shape and characteristics of the products or services that support the ability to meet the needs promised.

Quality and customer satisfaction are closely related, therefore, the quality of giving a boost to consumers to establish a strong bond with the company. In the long term, these bonds allow companies to understand thoroughly the expectations of consumers and their needs. Thus, companies can increase customer satisfaction where the firm maximizes the consumer's experience a pleasant and meminimum consumer experience less enjoyable.

In the end, customer satisfaction to create loyalty to the company that provides satisfactory quality, Kotler (2016) states that: "the satisfaction is feeling happy or disappointed someone who comes from a comparison between her impression of the performance (yield) of a product with expectations".

According to Lamb (2006), "states that loyalty is an old word that is usually used to describe the loyalty and obedience to the state, movements or individuals." Loyalty is used in a business context, to describe the willingness of customers to continue to use the products or services of the company in the long term ,

Consumer loyalty is customer loyalty that is presented in a consistent purchase of the product or service all the time and there is a good attitude to recommend other people to buy the product. Sesunggunhnya indication that loyalty required a measurement of the attitudes combined with a measurement of the behavior.

There is a renewal in this study is their customer satisfaction mediating variables that affect the relationship between brand experience and loyalty, as well as quality of service and loyalty. The renewal is based on research conducted by Alexander et al. (2013) and Paramita et al. (2016). Lara et al. (2017) mentions that the brand experience has a significant impact on customer loyalty, which means that when consumers have a good experience on the brand, the consumer will also have a high loyalty. While the research conducted Anthony et al. (2013) in 
his study mentions that brand experience have no significant effect on loyalty.

This research is the development of some previous studies that have pointed out above, by taking the title: "THE INFLUENCE OF BRAND EXPERIENCE AND SERVICE QUALITY TO CUSTOMER LOYALTY MEDIATED BY CUSTOMER SATISFACTION IN STARBUCKS COFFEE MALANG".

Background Based on these, the formulation of the problem to be researched are:

1. Are brand experience affect the increase in customer loyalty Starbucks Coffee Malang?

2. Is the quality of service affect the increase in customer loyalty Starbucks Coffee Malang?

3. Are brand experience affect the improvement of customer satisfaction Starbucks Coffee Malang?

4. Is the quality of service affect the improvement of customer satisfaction Starbucks Coffee Malang?

5. Is influence consumer satisfaction increase customer loyalty Starbucks Coffee Malang?

6. Are brand experience affect the increase in customer loyalty mediated by customer satisfaction Starbucks Coffee Malang?

7. Is the quality of service affect the increase in customer loyalty mediated by customer satisfaction Starbucks Coffee Malang?

\section{Research purposes}

Based on the formulation of the problem above, the purpose of this study is:

1. Analyzing the influence of brand experience to increase customer loyalty Starbucks Coffee Malang.

2. Analyzing the influence between quality of service to increase customer loyalty Starbucks Coffee Malang

3. Analyzing the influence of brand experience to increase customer satisfaction Starbucks Coffee Malang.

4. Analyzing the influence between quality of service to increase customer satisfaction Starbucks Coffee Malang.

5. Analyzing the influence of customer satisfaction on customer loyalty enhancement Starbucks Coffee Malang.

6. Analyzing the influence of brand experience to increase customer loyalty mediated by customer satisfaction Starbucks Coffee Malang.

7. Analyzing the influence between quality of service to increase customer loyalty mediated by customer satisfaction Starbucks Coffee Malang.

\section{MATERIAL AND METHOD}

This research is an explanatory research with a quantitative approach. Explanatory research is research that explains the causal relationship between the variables through hypothesis testing research is called research hypothesis or research explanation. This research method can be used with more terms and more comprehensive than other methods and provide cutting edge information that is beneficial to the development of science, (Denscombe, 2007)

Place of research carried out at Starbucks Coffee Malang City Point Floor 1 . When the study was conducted from March to April 2018. The population used in this study is a customer of Starbucks Coffee in Malang. The samples in this study are customers who come to Starbucks Coffee in Malang. In this study, using sampling techniques are non-probability sampling. Widayat \& Amirullah (2012), states that the selection of the sample by using Non Probability Sampling researchers can at will or consciously decide whether the elements into the sample. This means that the possibility or chance of a person or object to be elected to unknown samples.

Criteria for the sample to be used in this study are:

a. The age of respondents was seventeen years old and older (> 17 years). Age is based on Law No. 23 of 2002 on the Protection of Children is an age that is no longer categorized as children, in other words, already in adulthood who are consumers of Starbucks Coffee Malang.

b. Ever visit and make purchases at Starbucks Coffee Malang more than 1 time.

\section{SCHEMA 1.1 CONCEPTUAL FRAMEWORK RESEARCH}

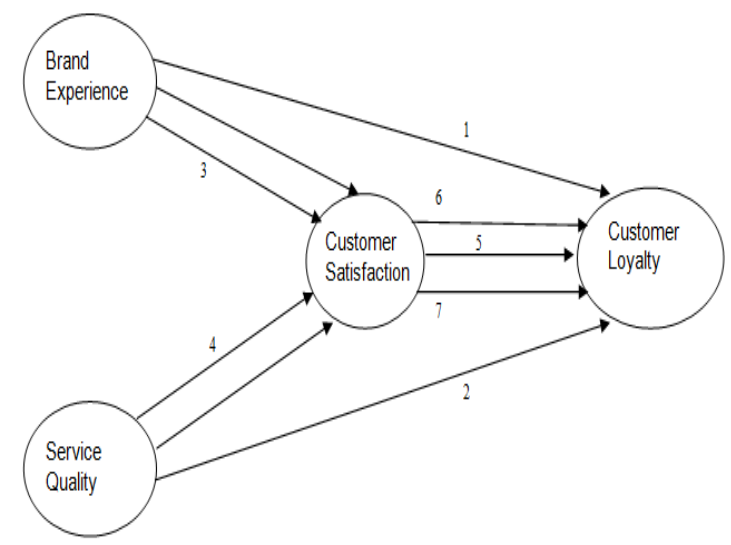




\section{Data Collection}

Primary data collected in this study the researchers obtained by distributing questionnaires to the respondents to be examined to find out the opinion of the respondents about the influence of brand experience and service quality on customer loyalty mediated customer satisfaction. Primary data in this study was a questionnaire. The primary data collection to 180 respondents to fill out a questionnaire distributed directly to the respondents are made in the study sample.

Methods of collecting primary data on current research is using the survey method using a questionnaire. This questionnaire is intended only for customers of Starbucks Coffee Malang coming to Starbucks Coffee unfortunate and meet the criteria of a sample that is aged 17 years and over.

Variable Measurement techniques in this study using a questionnaire containing questions that must be answered by the respondents and responded by selecting one appropriate answer, using a quantitative questionnaire litkert scale numbers 1 through 5, where 1). Strongly disagree 2). Tiidak agree 3). Hesitation 4). Agree and 5). Strongly agree. Data analysis was conducted in the present study using the Smart-PLS 3.0.

\section{RESULT AND DISCUSSION}

Table 1.1. Respondents Characteristic

\begin{tabular}{|l|l|}
\hline characteristics & Frequency (\%) \\
\hline GENDER: & $59.6 \%$ \\
Man & $40.6 \%$ \\
woman & \\
AGE: & $5.6 \%$ \\
20-19 Years Years & $29.4 \%$ \\
$26-30$ Years & $51.7 \%$ \\
31-35 Years & $12.8 \%$ \\
> 35 Years & $0.6 \%$ \\
EDUCATION: & \\
elementary school & $1.7 \%$ \\
junior high school & $7.8 \%$ \\
graduation & $9.4 \%$ \\
finished school & $42.8 \%$ \\
College student & $38.3 \%$ \\
Graduated College & \\
WORK: & \\
Government employees & $2.8 \%$ \\
Private employees & $8.9 \%$ \\
entrepreneur & $13.9 \%$ \\
College student & $42.8 \%$ \\
Not yet working & $31.7 \%$ \\
\hline
\end{tabular}

\section{Research Instruments Test}

\subsection{Validity test}

Validity test used to measure whether or not a valid or invalid instrument used. Measuring the level of validity in this research is done by calculating the correlation score between scores of each of the questions with a total score. Testing criteria used are comparing the test results with numerical tables on the basis of decision-making:

1) If the calculation results positive $r$, and $r$ results $>r$ table, then the variable is valid.

2) If $r$ is negative calculation result, and the result $r<r$ table, then the variable is not valid.

\subsection{Test Reliability}

A measurement (instrument) can be trusted if the number of times execution of measurements of the same group of subjects obtained relatively similar results. examination reliability of the instrument performed on the items that are valid questions. The instrument is declared reliable if the reliability value obtained reaches 0.6 . Reliability test results are presented in the table above shows that the Cronbach alpha greater than 0.6 so that the instruments used otherwise reliable.

\subsection{Classical Assumption Test \\ 2.3.1 Normality Test}

Normality test aims to test whether the regression model, or residual confounding variables have a normal distribution, because the F-test and t-test assumes that the value of the residuals follow a normal distribution (Ghozali, 2009: 147).

\section{Table 2.1 Normality Test}

\begin{tabular}{|ll|r|r|r|r|}
\hline & & \multicolumn{1}{|c|}{$\mathrm{X} 1$} & \multicolumn{1}{c|}{$\mathrm{X} 2$} & \multicolumn{1}{c|}{$\mathrm{Z}$} & \multicolumn{1}{c|}{$\mathrm{Y}$} \\
\hline $\mathrm{N}$ & & 180 & 180 & 180 & 180 \\
Normal Parameters & Mean & .0003430 & .0053440 & .0008770 & 13,69560 \\
& Std. Deviation & .0001039 & .0029383 & .0005744 & 16,90669 \\
Most Extreme & Absolute &, 188 &, 262 &, 271 &, 377 \\
Differences & Positive &, 188 &, 262 &, 271 &, 377 \\
& Negative &,- 148 & -176 &,- 189 &,- 206 \\
Kolmogorov-Smirnov Z & &, 593 &, 828 &, 858 & 1,193 \\
Asymp. Sig. (2-tailed) & &, 873 &, 499 &, 453 &, 116 \\
\hline
\end{tabular}

Source: primary data in processing (2018)

From the test results in the above table it is known that the test results are known to have the value One Sample Kolmogorov-Smirnov Test for at $0.593 \times 1, X 2$ of 0.828 to $Z$ of 0.858 and 1.193 for $Y$ for the show shows signfikansi level above $5 \%$. Data are expressed in normal distribution when generating value, A.symptotic Significance $>a=$ $5 \%$. 


\subsubsection{Test Multikoreliniaritas}

Multicolinearity means there is a perfect linear relationship or certainly among some or all of the independent variables that explain from the regression model. Multiple linear regression model is said to be good if it does not happen multikolinieritas (Singgih, 2002: 203). This assumption is necessary to determine whether there is an independent variable that has similarities with other independent variables.

Table 2.2 Test Multicolinearity

\begin{tabular}{|ll|r|c|}
\hline \multirow{2}{*}{ Model } & \multicolumn{2}{|c|}{ Collinearity Statistics } \\
\cline { 3 - 4 } & & Tolerance & \multicolumn{1}{c|}{ VIF } \\
\hline 1 & Brand Experience $(\mathrm{X} 1)$ & .874 & 1.485 \\
& Kualitas Layanan (X2) & .747 & 1.827 \\
& Kepuasan Pelanggan (Z) & .814 & 1.344 \\
\hline
\end{tabular}

Source: primary data in processing (2018)

Based on the results of the analysis are presented in the table above are known hasli multicolinierity test has VIF Tolerance under 5 with close to 1 , it indicates not happen multikolinieritas.

\subsubsection{Test Heteroskedesitas}

In heteroskedesitas testing aims to test whether a regression model, occur inequality residual variance from one observation to another observation. If the variance of the residuals some observations to other observations are different, then there heterokedastisitas.

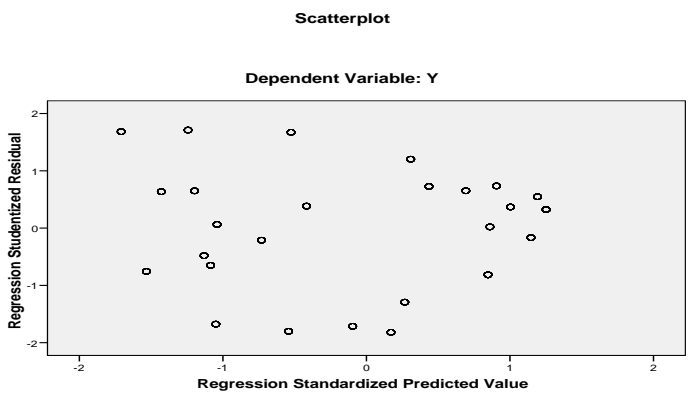

Source: primary data in processing (2018)

\subsubsection{Test of autocorrelation}

Autocorrelation namely the relationship between the variable itself, errors appear generally occurs on time series data (time series). If symptoms of autocorrelation the least square estimator becomes inefficient that the estimated coefficients obtained becomes inaccurate (Singgih, 2002: 216).
Table 2.3. autocorrelation test

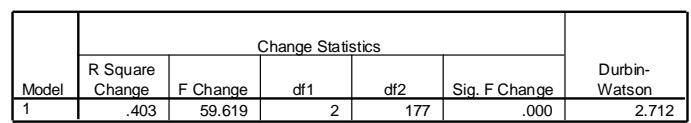

Source: primary data in processing (2018)

Based on the presented table is known the value of DW of 2,712 that indicates detected using Durbin Watson Test (DW-test) teleh qualify DW which is on the value of -4 and 4 . In order to detect the presence or absence of autocorrelation, then testing Durbin Watson (DW) with the following conditions :

1). Positive autocorrelation occurs if $d w$ lies between $0<\mathrm{DW}<\mathrm{dL}$.

2). Negative autocorrelation if $d w$ lies between $4-\mathrm{dL}<\mathrm{DW}<4$

3). No, autocorrelation positive or negative autocorrelation if the value of $\mathrm{dw}$ located between $\mathrm{dU}<\mathrm{DW}<4$ - dU.

4). Hesitate no positive autocorrelation (no inference) if dug value lies between $\mathrm{dL}<\mathrm{DW}<\mathrm{dU}$.

\section{Analysis of Data}

\subsection{Multiple Linear Regression Analysis}

Multiple linear statistical analysis in this study to determine and influence of the variables studied using SPSS version 20 for windows with the results the following conclusions:

1. There Influence Consumer Brand Loyalty Experience proved from $6.815 \mathrm{~F}$ count $>\mathrm{F}$ table $(2,260)$ and 3,107 t count $>t$ table $(1.980)$ then the hypothesis is accepted it means there is significant influence of the Brand Experience to Customer Loyalty with singnifikan $0,000<$ ? 0.05 . Then note also that the value of $R$ Square of 0.211 means that the influence of the Brand Experience against $21.1 \%$ Consumer Loyalty.

2. There Influence Customer Loyalty Service Quality evidenced by $95.040 \mathrm{~F}$ count $>\mathrm{F}$ table $(2.260)$ and 9.749 t count $>t$ table (1.980) then the hypothesis is accepted it means there is significant influence of services quality to Consumer Loyalty with signification $0,000<$ ? 0.05 . Then note also that the value of $R$ Square of 0.348 means that the influence of the quality of service to the Consumer Loyalty of $34.8 \%$.

3. There Influence brand Experience against Customer Satisfaction evidenced by $8.463 \mathrm{~F}$ count $>\mathrm{F}$ table $(2.260)$ and $3.016 \mathrm{t}$ count $>\mathrm{t}$ table (1.980) then the hypothesis is accepted it means there is significant influence of the Brand Experience to Customer Satisfaction with signification $0,000<$ ? 0.05 . Then note also that the value of $R$ Square of 0.295 means that the 
influence of the Brand Experience to Customer Satisfaction by $29.5 \%$.

4. There is the influence of Quality of Service Customer Satisfaction evidenced by $41.029 \mathrm{~F}$ count> F table (2.260) and $6.405 \mathrm{t}$ count $>\mathrm{t}$ table (1.980) then the hypothesis is accepted it means there is a significant influence on the quality of service to customer satisfaction with signification $0,000<$ ? 0.05 . Then note also that the value of $R$ Square of 0.287 means that the influence of Quality of Service Customer Satisfaction 28.7\%.

5. There's effect Consumer Satisfaction Loyalty evidenced by $120.702 \mathrm{~F}$ count $>\mathrm{F}$ table (2.260) and $10.986 \mathrm{t}$ count $>\mathrm{t}$ table (1.980) then the hypothesis is accepted it means there is significant influence of customer satisfaction on consumer loyalty with signification $0,000<$ ? 0.05 . Then note also that the value of $R$ Square of 0.404 means that the influence of customer satisfaction on consumer loyalty of $40.4 \%$.

6. There is the influence of Brand Experience Loyalty Consumers are mediated by customer satisfaction as evidenced by $F$ count 62.789> F table (2.260) and $t$ value $11.061>t$ table (1.980) then the hypothesis is accepted it means there is significant influence of the Brand Experience Toward Consumer Loyalty mediated by Consumer Satisfaction with signification $0,000<$ ? 0.05. Then note also that the value of $R$ Square of 0.415 means that the influence of customer satisfaction on consumer loyalty of $41.5 \%$.

7. There is the influence of Quality of Service Loyalty Consumers are mediated by customer satisfaction as evidenced by $F$ count 95.040> F table (2.260) and $t$ value 9.749> $t$ table (1.980) then the hypothesis is accepted it means there is significant influence of service quality on customer loyalty mediated by consumer satisfaction with signification $0,000<$ ? 0.05 . Then note also that the value of $R$ Square of 0.444 means that the influence of customer satisfaction on consumer loyalty by $45.4 \%$.

\subsection{Hypothesis testing}

Testing the hypothesis in this study using path analysis, which aims to measure the overall effect of brand experience and service quality on customer loyalty mediated customer satisfaction. The results, as presented in the figure below:

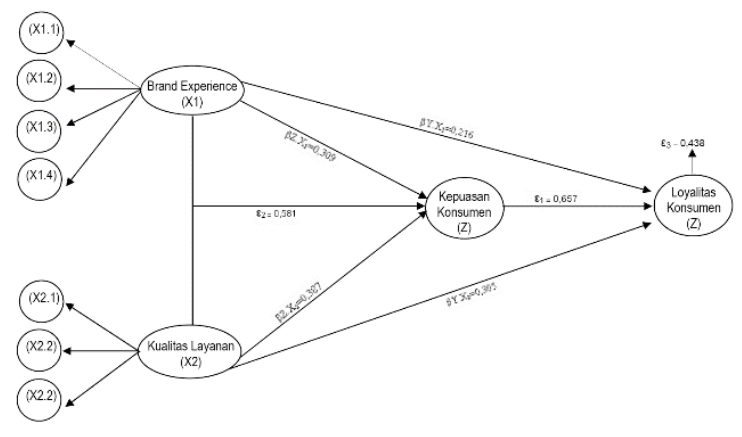

Based on a model that has served the daoat known that:

1. Brand experience on consumer satisfaction with the value of 0.309 or $30.9 \%$

2. The quality of service to customer satisfaction with the value of 0.387 or $38.7 \%$

3. Brand experience on consumer loyalty to the value of 0.216 or $21.6 \%$

4. Quality of service consumer loyalty to the value of 0,305 or $30.5 \%$

5. Effect of brand experience and service quality customer satisfaction with the value of 0.581 or $58.1 \%$

6. Effect of brand experience and service quality on customer loyalty with a value of 0.657 or $65.7 \%$

7. Effect of brand experience and service quality on customer loyalty mediated consumer satisfaction with the value of 0.438 or $43,8 \%$

So this research provides clear results that are pengaruh brand experience and service quality to increase customer loyalty mediated customer satisfaction. 


\section{CONCLUSION}

Based on the formulation of the problem, objectives and discussion in this study on the influence of brand experience and service quality on customer loyalty mediated by customer satisfaction can be concluded thatfor the development of a buying cycle shows, there are two things that affect a customer re-purchase, ie post-purchase evaluation and decision to buy back. Customers consciously or unconsciously always evaluates transactions. When a buyer is satisfied or discontent is not too big to be used as a basis for consideration to switch to a competitor, then the decision to re-purchase might happen.

Loyalty is a term that has been used to describe the traditional loyalty and devotion to country, ideals, or individual. In a business context, loyalty is used to describe the willingness of customers to continue to subscribe to a company in the long run by buying and using goods and services over and, better still exclusively and voluntary recommend the company's products to friends. Moreover, in the context of loyalty, people today are growing term waders (defection) is the term used to describe customers who switch their loyalty to competitors. Reichheld and Sasser popularize the term zero defection, that keep customers up to does not happen crossings. Results of research conducted by Evanschitzky et al. (2006), quoted from Setiawan (2009) showed that customer commitment and significant positive effect on attitudes and loyal behavior. Commitment to sustainable impacts on the behavior of loyal customers.

In order to increase customer loyalty Starbucks Coffee Malang then the satisfaction of services provided must be improved, the work needs to be done is to give attention in handling customer complaints. To handle customer complaints, required an effective complaints process handler that can be started from the identification and determination of the source of the problems that cause customer dissatisfaction and complain (complain). This step is a step that is vital for determining the effectiveness of the subsequent steps. Source of this problem needs to be addressed, followed up, and aligned to be in the future is not the same problem arises. In this step the employee responsiveness, speed and accuracy in handling is essential.

Quality of service is an expected level of excellence and control over the level of excellence to meet customer desires. Customer complaint is an action or reaction that is driven by a sense of dissatisfaction of customers towards the products or services offered by the company, it can be concluded that the quality of service of the complaint is the level of excellence of the activities offered by the company to the customer with the aim to tackle or handle the action or reaction to customer dissatisfaction the products or services offered by Starbucks Coffee Malang.

\section{Research limitations}

This study through the steps - steps that are required in scientific research and through the refinement process repeatedly - again, but in this study there are limitations to the study, which could be enhanced in future research. Limitations of this study are the variables used in this study had an influence on loyalty, so it needs to be reconsidered for the use of other variables such as brand equity and repeat purchases.

Respondents in the study are currently unknown range of income levels, so that the research findings is not currently able to describe the characteristics of respondents in choosing the brand of Starbucks Coffee by income ranges from a variety of respondents surveyed. The study only those customers who come to Starbucks Coffee and only at Malang city. So the generalizability of the findings is limited in the area of research.

\section{Acknowledgment}

Authors are grateful to God for the completion of this scientific work. Not least, thanks to the late father giving a mandate to continue the study of this master, and mother, and sister, best friends and friends who always give support, and thanks to Mrs. Dr. Siti Aisjah, SE., MS and Mrs. Dr. Astrid Puspaningrum, SE., MM. to the guidance given during the writing process. The author also wishes to thank Mr. Ainur Rofiq, Ph.D. and Mr. Dr Fatchur Rohman. for research evaluation.

\section{REFERENCES}

[1]. Aaker, DA, Kumar, V. and Day, GS 2007. Marketing Research (ninth edition)., John Wiley \& Sons, Inc., US

[2]. Alma, Buchari. Pamasaran 2005. Marketing Management and Services. Publisher CV Alfabeta, Bandung.

[3].Arikunto, Suharsimi. 2006. Research Procedure, A Practice Approach. Publisher PT Rineka Cipta, Jakarta.

[4]. Azize Sahin et al. 2011. The effect of Brand Experiences, Trust and Satisfaction on building 
Brand Loyalty; An Empirical Research On Global Brands

[5]. Brakus, J. Josko, Bernd H. Schmitt, and Lia Zarantonello. (2009). Brand Experience: What Is It? How Is It Measured? Does It Affect Loyalty ?. Journal of Marketing, 73, 52-68.

[6]. B. Ramaseshan (2014) concerning; "Connecting the dots between brand experience and brand loyalty: The mediating role of brand personality and brand relationships.

[7]. Cherng, GD (2013) about; On the relationships among brand experience, hedonic emotions, and brand equity

[8]. Deni Wardani (2016) about; "Analysis of Brand Experience, Brand Satisfaction and Brand Trust Relationship to Brand Attachment"

[9]. Denscombe, Martyn. 2007. The Good Research Guide. Cosial for Small-Scale Research Project. Thirt Edition. Open Univeristy Press, New York, USA,

[10]. Donant Alananto Iskandar (2013) about; "The Effect of Brand Experience and Satisfaction As Intervening Against Starbucks Consumer Loyalty.Ultima Management Vol 5. 1. June 2013

[11]. Griffin, Jill. 2007. Customer Loyalty: How to Earn It, How to Keep It, Jossey Bass, United States. [12]. Grönroos, Christian. 2011. Service Management and Marketing: Customer Management in Service Competition, 3rd Edition. Massachusetts, Lexington.

[13], Hurriyati, Ruth. 2010. The Marketing Mix and Customer Loyalty. Third mold, Publisher Alfabeta. Bandung.

[14]. Imam Ghozali. 2005. Applications Multivariate Analysis with SPSS Program. Publisher Agency Diponegoro University. Semarang

[15]. Jonathan, Sarwono. 2007. Path Analysis for Business Research with SPSS. Publisher Andi Offset. Yogyakarta.

[16]. Keller, Kevin Lane. 2008. Strategic Brand Management: Building Measuring and Managing Brand Equity (3th ed.), New Jersey: Pearson Education.

[17]. Kotler, P., \& Pfoertsch, W. 2016. In the B2B brand management. Publishers, PT. Bhuana Popular Science. Jakarta.

[18]. Kusuma, Yohanes Surya. (2014). Influence of Brand Experience against Brand Loyalty through Brand Satisfaction and Brand Trust Harley Davidson in Surabaya. Petra Journal of Marketing Management, 2 (1), 1-11.

[19]. Lamb, Charles W. and Joseph F Hair. 2006. Marketing. Translated By David Octarevia. Book
Two. First Edition. Publisher Salemba Four. Jakarta.

[20]. Lara Maisyarani (2017) about; "The Effect of Brand Experience, Brand Trust and Brand Image Of Brand Loyalty (In Users Levi's Jeans brands in Padang).

[21]. Lovelock, Christopher H. 2006. Services Marketing Management (Translation) Publisher PT. Gramedia Group Index. Jakarta.

[22]. Malhotra, Naresh. 2010. Marketing Research: An Applied Orientation (6th ed.), New Jersey: Pearson Education.

[23]. Mowen, J and Minor, Michael. Fifth Edition, 2002. Consumer Behavior. Erland. Jakarta.

[24]. Parasuraman, A., Zeithaml, VA, Malhotra, A. 2005. ES-QUAL A Multiple-Item Scalefor Assessing Electronic Service Quality. Journalof Service Research, 1-21.

[25]. Paramita Nyohardi. 2016. Effect of Brand Experience against Brand Loyalty Through Brand Satisfaction and Brand AttitudeStarbucks Coffee. Journal of Business and Management / Volume 52/11 / November -2016: 159-184

[26]. Oliver, P. 1997. Customer Loyalty: Research, Theory and Practice. United Kingdom, John Wiley \& Sons. Ltd.

[27]. Rangkuti, Freddy. 2008. The Power Of Brands. Revised Edition. Publishers, PT. Gramedia Pustaka Utama, Jakarta.

[28]. Rajumesh, Sivarajah. (2014). The Impact of Consumer Experience on Brand Loyalty: The mediating Role of Brand Attitude. International Journal of Management and Social Sciences Research (IJMSSR), 3 (1), 73-79.

[29].Hadi Riyan W (2015) about; "Explanatory Study of Brand Experience, Satisfaction and Brand Brand Brand Loyalty Of Trust In Global Automobile Brand Type MPV in Surabaya.

[30]. Rony, Arthana. PengaruhBrand 2016. Exposure and Brand Experience against Brand Trust and Brand Recall (Study on Smartphone Product in Malang City area).Journal of Business Economics Year 21, No. 2, October 2016

[31].Rodrigues, LGP, 2010. Effects of In - Store Promotion on Brand Awareness. Thesis, Lund University.

[32].Santoso, Singgih. 2007. Exercise Book SPSS Parametric, PT. Elex Media Komputindo. Jakarta. [33]. Schiffman, J Leon G. 2010. Consumer Behavior, Pearson Education, New Jersey.

[34]. Singarimbun \& Effendi. S. 2001. Survey Research Methods. Publisher PT Pustaka LP3ES Indonesia, Jakarta.

[35]. Sugiyono. 2008. Understanding Qualitative and Quantitative Research. Equipped Sample 
Proposal and Research Reports. Publishers, Alfa Beta. duo

[36]. Sumarwan, U. 2003. Consumer behavior, theory and practice in marketing. Jakarta: PT. Ghalia Indonesia

[37]. Sunarto, 2004. Principles - Principles of Marketing. Publisher AMUS, UST and Mahenoko Total Design, Yogyakarta.

[38]. Supranto. 2011. Consumer Behavior and Marketing Strategy, Partners Media Discourse, Jakarta.

[39]. Stanton, William, J. 2001. Principles of Marketing Volume Seventh, the publisher, Jakarta.

[40] .Taroepratjeka. Consuming Culture 2013. Indonesian Community Coffee.

http://library.usu.ac.id/.download / budayangopi.pdf. Accessed on a Sunday, November 5th, 2017.
[41]. Temporal, Paul. 2004. Advance Brand Management. John Willey \& Sons, Press. New York.

[42]. Tilde, Heding and Charlotte, FK2009. Brand Management: Research, Theory and Practice. Routledge, London.

[43]. Tjiptono, Fandi. 2001 Marketing Strategy. Publisher Andi Offset, Yogyakarta.

[44]. Tjiptono, Fandi. Management \& Marketing 2006. Contemporary Perspectives. Publisher Andi Offset, Yogyakarta.

[45]. Wyckof, 2002, Principles of Marketing, Seventh Edition, Volume I, Erland, Jakarta.

[46]. Zeithaml, VA, Bitner, MJ, \& Gremier, DD 2009. Service Marketing. New York: The McGrawHill Companies. 